in a rery good state of health, but on examination was discovered to have a largesized calculus in his bladder. Mr. Earre could not succeed in introducing a sound of the ordinary curvature, which dificulty he imagined to originate from i malformation of the corpus spongiosum penis. A staff of smaller curvature was first passed, and the operation performed in the usual manner. The stone being very large and the pelvis small, it was necessary to use some force in the extraction, and a portion of the stone was broken off in the bladder. This was aftervards removed by the scoup. Mr. EARLE observed after the operation, that from the size of the calculus he had no doubt but that it had been forming from birth. From its appearance he said he should pronounce it to he composed of cystic oxyde externally, and internally of lithic acid, but that this would be clearly ascertained by Dr. Hue, to whose analytical tests the stone was about to be subjected. The result has not yet been stated.

October 7. The water passes freely through the wound in the perineum, and also by its natural passage. The little fellow says he experiences no pain, and appears to be going on very favourably.

\section{BRITISH SCIENTIFIC ASSOCIATION.}

Srr C. BeLl read a lecture on the nervous system, the most important part of which was his announcement of two discoveries by his assistant, $\mathrm{Mr}$. Newport, of the spinal marrow of the lobster, and a medullary tract of spinal marrow in the sphinx ligustra, from which nerves wore distinctly traced extending to the respiratory organs of that animal. These new facts analogically confirm what has been usually regarded as the most dubious part of Sir C. Bell's views of the nervons system. The only other novelty in his lectures was a recominendation of some improvements in the mode of examining the brain; he strongly advised anatomists to use brains that had been preserved for several months in spirits, declaring, that in them the course of the fibres could be traced more distinctly than in others.

Dr. Prout's Atomic Views.-An im. portant discussion in the Chemical Section arose from the attack made by Professor Clarke, of Aberdeen, on Dr. Prout's account of the atomic analysis of carbonate of lime. Dr. Thomson ably defended Dr. Prout's views; he stater, that what is chemically designated an atom is, in fact, a congeries of atoms, for it was little short of absurdity to speak of the fraction of an atom. It was stated as Dr. Prout's opinion, that all clementary substances are multiples of hydrogen. Thus carbon, oxygen, \&c., are, in reality, certain combinations of atoms of hydrogen. This singular theory has revived the popularity of the German hypothesis, first broached, we bclieve, by Kant, that cverything is elininated from a common principle.

HYDROPHOBIA COMMUNICATED BY A Cow.-It has been asserted by some who hold a high rank both in the veterinary and medical world, that rabies can be communicated by those animals only who use their tecth as weapons of offence. We have often wondered at the unhesitating and dogrnatical way in which this assertion is made, for we arc ignorant of any theoretic principles on which it could be possibly grounded; it is contrary to occasional facts, well known to all who have paid attention to the subject; and it is likely to lead to dangerous and fatal neglect of proper precautionary means. A late number of the Joumal Theorique has added another to the cases of death succeeding to inoculation with saliva from a rabid ruminant, and also of the fearful period during which the virus may remain inert in the frame. A cov in the department of Jura was bitten by a dog affected with rabies. Some time afterwards she became dull, and refused all kinds of food. She approached some water, which was offered to her, and macle repeated but fruitless efforts to swallow it. A woman that had the care of her imagined that some foreign body was lodged in the pharynx, and prevented the animal from swallowing; and she thrust her hand into the mouth of the beast, and to the very back part of it, but found nothing. In doing this her hand was slightly scratched by one of the teeth of the animal. It was soon afterwards sufficiently plain that the cow was rabid, and she was destroyed by order from the magistrates. A year afterwards the woman began to have frightful dreams, in which she thought that she was pursued by two enraged animals, - the cow, and the dog by which it had been bitten. She had dread of water, and she died of rabies in a state of horrible suffering, attended by circumstances peculiarly lamentable.-Veterina. rian, oct.

To the Editor of THE LANCET.Sir, You will oblige me by inserting the following letter with regard to small doses of calomel in the cholera, and at the 
same time do justice to Mr. E. R. Mark, ' gius Professor? - It enabled me to pass it Surgoon of Newcastle, whoin I was with, better.

during the first attack of cholera at that 7 ; 0 . Perhaps less than a year's study town. Long previous to either an attacle would have bcen suficient for passing the in Sunderlard or Newcastle, Mr. Mark sort of examination you appear to have mentioned to me his determination to undergone? - I do not consider that $I$ siupursue no other course of treatment than died my profession at Oxford.

that of giving small doses of calonel combined with a very small proportion of opium, should Newcastle be risited with the disease; and when it did make its appearance in Newcastle, he adopted this treatmont, and continued it through the whole time of its invasion, with the greatest success. MIany surgeons adopted the same comrse of treatment, and found it cqually successful. I remain, your most obedient humble servant,

Samuel Coates Mason.

No.17, Gower Place, Oct. 8, 1834.

Specimen of Dr. Macmichael's EviDFNCE BeFORE THE PARLIAMENTARY Commrate:-The Chairman asked this witness in the course of his examination,"In your time did Oxford possess any competent means of teaching medicine?" Dr. Macmichael answered, "Yos," when the following questions and answers were exchanged. The manner in which the witness supported his first affirmative answer by subsequent negative replies, was worthy of the Royal College which supplied him. (Vide "Medical Evidence" LANCET edition, page 53) :-

759. Describe the courses of lectures given in your time, and the subjects of the various branches of medical science taught? - The lectures on anatomy were very good.

760. Were there any lectures on physiology ?-No.

761. Any on morbid anatomy?-That was included in the lectures on anatomy.

762. Any on pathology ?-No.

763. Any on inateria medica? - No.

764. Any on therapeutics? - I was a clinical pupil of Dr. Wall's.

765. There was clinical practice?-Yes; but he gave clinical lectures.

766. There was no series of such lectures? - No, but the cure of patients in the hospital was the best way of teaching that.

767 . What period of attendance on hospital practice was considered necessary? -I do not know; there was no stipulated time; I attended for a year.

768 . It was entirely voluntary on your part?-I paid THE FEES.

769-That was not essential to your passing your examination before the $\mathrm{Re}$.

QuACE Dentists.-A correspondent, who has given us his name and alliress, informs us, that the poisonous mixtrues of the Drs. JoRDAN of Newman-street and Caroline-street, Bedford-square, having ceased to find purchascrs, the proprietors have adopted a new mode of making inoney; they have changed their names and become professors of the dental art, holding out the most magnificent promiscs of relief in every case of suffering arising from the diseases of the teeth and gums, and informing the public, in a spirit of fairness and equity, at the one establishment (for there are two), that the charges are "the same as at Constantinople," and at the other, that "the charges are the same as at Kamschatka." The trade is carried on at the ofd houses, under the names of Monsieur Le Drag, and $\mathrm{Mr}$. Johnson.

of

ssic Frsh.-At the late meeting itish Association at Edinburgh, Mr. Blackadder exhibited a fossil fish from Glamis Millstone Quarry, which is situated in the old red sandstone. M. Agassiz refers this fish to the family of the "Ganvides," and to his genus Cephalaspis, which is characterized by the immense "cuirasse" that envelops, or rather forms its head. This fish is quite new to the scientific world, and has been now found entire for the first time.

(From a Correspondent.) - The Solicitor to the self-appointed committee of lecturers (Messrs. Geo. Tuthill, Wm. Lawrence, and Thos. Watson) who opposed the grant of a charter to the London University before the Privy Council, and then presented a lawyer's bill of $440 l$. to the lecturers on whose behalf they professed to act, with a request for its immediate payment,- the solicitor to that committee was the brother of William Lawrence, surgeon, one of the committee, and mem * ber of the Council of the London College of Surgeons.

The following adrertisement contained in the Cork Eventag Herald, has been forwarded to 11 : :- "To the Sulscribers to 
the Cork Gencral Dispensary.-Gentlemen,- I take this public manner of resigning the situation of one of your Phy sicians, after a service of eight years, four and a half of which were entirely gratuitous, and the remainder of the time on a salary that could be called but nominal, viz.:-twenty-five pourds per annum. I regret to say that under the management of your conducting Committee no physician, with the feelings of a gentleman, can continue to act. $I$ have the honour to be, Gentlemen, your obedient humble servant, W. F. Porrer, 72, Patrick-street, Cosk.

"*** This is the second similar resignation within three months, from the same cause. Sept. 16, 1834."

\section{CORRESPONDENTS.}

Aftar having carefully read the letter of "A Governor in the Southern district of the London Southwark Midwifery Institution," we confess that we do not think the gravamen expressed in it, a just subject of complaint. The motion of Dr. Waller seems to have been openly made and publicly discussed, and the decision doubtless was fairly obtained from the majority of those who were present. Our correspondent must know that we are wholly opposed to these mismanaged and misnamed petty medical " charities," which are instituted and supported to serve the private ends of the medical officers; and we are by no means surprised or sorry to hear of events occurring in the management of them which tend to "injure their prosperity" by disgusting and alienating the subscribers. 'The supporters of the resolutions on this occasion are accused of having been actuated by feelings of personal interest. Doubtless these had their weight, but a similar charge may be brought against the manaters, real or ostensible, of every dispensary, infirmary, and lying-in institution, in London. At any rate, if Dr. Waller rules in the London and Southwark Midwifery Institution, the subscribers are willing subjects, for the threat of resignation was submitted to by them with readiness. The fittest source for complaint will arise when any of the governors can show that the medical oficer who has thus voluntarily doubled his duties, neglects the patients who are placed under his care.

The following communications have been received:--Mr. Wm. English's letter,-Mr. Teatpeson's cases of lithotrity, $-D r$. Pryer's case of spontaneous restoration of sight,-Mr. Mordey's remarks on ipecacuanha in cholera, $-D r$. Curtin's letter on salt emetics in cholera,-a lctter headed pupils (which we have not room futher to notice this week $),-R \quad O .$, Head Quarters,"- Ir. S. $P$. Monck, -W' H. O., $M$. IV. A. Thomson,$B$, ightoniensis (the communication has been $c x$ cluded hitherto from want of space)-and $1 \mathrm{H}$. Llowi son, for whose lecture we shall not be able to afford room.

The letter on the French Medical Concours is incomplete. The sheets after folio 8 have not been sent, consequently, also, there is no signature to the communication.

As we are very much pressed for space, and the subject has already been ably discussed in the work of $M r$. Wright, we ale indiced to decline the remarks and proffered cases forwarded by that gentleman.

$W$. S. must be explicit.

We cannot suppose $M r . T . B . P$. to be really ignorant of the cause of the "s war." He must be fully aware that snch notifications are never made on the caids of respectable practitioners.

Tyro Medicus and Juvenis.-The replies would occopy a page. Our correspondents should ap. ply by letter, or by a friend, at the seat of learning itself.

If we did not think that Mr. $J . B-d$, of $S-t$, would be satisficd that oul reacons for withlolking his letter from publication were good, we wonld here explain them; but we believe that he will rely on the correctness of our decision against ils publication. We are sure that the caution is not hecessary, as no surgeon would buy an expensive in. strument, the use of which was not verified by expe. rience, and the personal charge of disingentousness should not go further in a public print, than it was pressed on a former occasion. Whuncver Mr. E. B. has perfected his apparatus, his account of it (if forwarted) should be accompanied by an engraving on wood, prepared for our columis.

Mr. Lumley informs us, that a life of LINACRE, " pliysician to Henry VIII., and founder of the College of Physicians," with memoirs of his contemporai ies, is in the press, mitten by tie late $\mathrm{D}_{1}$. Noble Jolnson, and edized by Mr. Graves, of the Inner Temple.

The Secretary of the " Weymouth and Dorchestcr Medico-Chinurgical Look Society," hag favomed as with the annud reports of that association. Whatever tend so unite the profession, either in local bodies or in the general mass, is a source of interest to $u$, and societies for medical discussion or the formation of libraries may always be arlvantageously founded. The libraries, however, should al switys be made libraries of "reference." Snch institutiuns are so yery rare in the profession, that it would be wise to devote the whole of the funds of book societies to the collection of the more costly productions. Periodicals are luxuries which all professional men who wish to keep pace with the knowledge of the times should purchase and ktep within reach. Their form, price, periods, and contents, are especially adapted for such an appropriation, and in the highest state of mental cultivation in the profession. Every man will bit under his own fig-tree with his own periodicals, fiesh and moist from the piess, no "secretary" daring to take them away for "further circulation."

Our second notice of Dr. Holland's work is unavoidably postponed.

Errata.-In leader, last week, pare 73, line 13, for labyrinth read labomatory. The error occurs only in part of the impression.

In Mr. Dermott's remarks, page 38 (Sept. 27), line 27, for on read or.

In Student's Number, page 7, College Regulations, article 2 , for six years read five years. 